\title{
A comparison of two maintenance strategies: reliability-centred maintenance and total productive maintenance
}

\author{
I.B. Hipkin \\ Department of Business Science, University of Cape Town. Private Bag, Rondebosch 7700, Republic of South Africa
}

Received March 1993, accepted June 1993

\begin{abstract}
Improvements in the manufacturing sector have been attained through the use of a variety of management interventions. These have all concentrated on materials management and the production process. One functional area that has been neglected is the maintenance of physical assets. In this article two maintenance management approaches are compared from a philosophical and strategic point of view: reliability-centred maintenance (RCM) and total productive maintenance (TPM). The two are conceptually different, although there are common elements. Reliability-centred maintenance provides a structured methodology and concentrates on technical issues such as failure consequences and the technical feasibility and effectiveness of maintenance, with some emphasis on the human factors. Total productive maintenance seeks to maximize equipment effectiveness by the complete elimination of failures and relies on the work of autonomous groups. Much emphasis is placed on the human component. From a strategic point of view, both approaches require organizational changes which may result in a dilution of managerial power.
\end{abstract}

Verbeteringe in die vervaardigingsektor is te weeg gebring deur verskeie bestuurspraktyke. Daar is meestal op die bestuur van grondstof en die produksieproses gekonsentreer. Minder aandag is aan die instandhouding van bates bestee. In hierdie artikel word twee instandhoudingsmetodes vanuit 'n filosofiese en strategiese oogpunt vergelyk: betroubaarheid-gekonsentreerde instandhouding (RCM) en totale produktiewe instandhouding (TPM). Die twee benaderinge verskil aansienlik, alhoewel dit ook gemeenskaplike elemente bevat. RCM voorsien 'n gestruktureerde metode gerig op tegniese probleme soos die gevolge van onderbrekinge en die tegniese haalbaarheid van instandhouding. TPM poog om die doeltreffendheid van loerusting te benut deur die uitskakeling van onderbrekinge, en maak staat op die werk van onafhanklike groepe. Heelwat klem word op menslike hulpbronne geplaas. Vanuit 'n strategiese hoek gesien, vereis albei metodes organisatoriese veranderinge wat kan lei tot 'n vermindering in die mag van bestuurders.

\section{Introduction}

Improvements in manufacturing have been sought through the implementation of a variety of management interventions, particularly over the last two decades. The late seventies and early eighties were concerned with the management of materials (materials requirements planning [MRP] and its derivatives). The Japanese influence dominated the mid- and late eighties with the introduction of a broader materials management philosophy using just-in-time (JIT), and the emphasis on quality, ultimately leading to total quality management (TQM). Quality enhancement has also been pursued through statistical process control (SPC). Computer applications have encouraged the use of a variety of other approaches such as computer integrated manufacture (CIM) and flexible manufacturing systems (FMS).

These approaches, conveniently reduced to three letter abbreviations, have singularly neglected the physical assets that actually manufacture items. The nineties appear to be the decade when the maintenance of facilities will receive the attention of researchers and manufacturers. Two maintenance philosophies have been developed, each from an entirely different origin. It is the purpose of this article to compare these two: reliability-centred maintenance (RCM) and total productive maintenance (TPM). A discussion of maintenance in general is presented, followed by a brief description of the two maintenance approaches. The underlying philosophies and methods of implementation of each are compared. The article is concluded with a discussion of the strategic status of RCM and TPM.

\section{Malntenance in perspective}

Maintenance is generally seen as providing a service to the production department. As such it has not been instrumental in contributing to the strategic direction of manufacturing organizations: the maintenance department has not been construed as constituting a 'competitive weapon' in the strategic framework proposed by Hayes \& Wheelwright (1984). The main developments in maintenance have been the implementation of planned maintenance systems (loosely equivalent to preventive maintenance - PM), and reliability studies. For decades the former has been widely accepted as the ideal of sound maintenance, and the latter has received theoretical treatment in academic joumals and research laboratories.

The early preventive maintenance era was characterized by planning systems and the contribution of maintenance to competitive advantage was measured by lowering maintenance costs. The westem reliance on preventive maintenance and associated systems has resulted in great efforts to measure performance and to report failures. The Japanese emphasis has been to improve performance and to prevent failures. Attempts to implement the theoretical findings of reliability research findings have led to hazard and operability studies and expert systems. Condition monitoring techniques are now widely available, both from a cost and ease of implementation point of view. With increasing use of automation and mechanization, manufacturing organizations will find that maintenance costs are unlikely to decrease. The aim of enhanced maintenance practices is to contain the rate at which maintenance costs are likely to increase. While improved technology may change the skills profile of production workers, any reduction in production manpower 'is likely to be offset ... by increases in maintenance and engineering' (Gold, 1989: 35).

Industrial accidents such as Piper Alpha, Chemobyl and 
Bhopal, and other safety and environmental issues have attracted the urgent attention of not only maintenance managers, but also of their chief executive officers. Legislation in both the United States and the European Community has been made far more stringent recently, with managers being held accountable to a greater extent than ever before. This places a heavy burden on the maintenance function.

The inability of preventive maintenance systems to bring about acceptable levels of safety and plant availability has led to a broad acceptance that the maintenance of plant and equipment needs to be reassessed. One of the reasons for this is the recognition that plant and equipment can fail in several ways. Nowlan \& Heap (1978: 46) found that equipment failures fall into two broad categories: those failures which are age-related and those where there is no relationship between age and the probability of failure. The traditional view of failure is the situation where a low level of random failures occurs after equipment has been installed until the 'life' of the equipment is reached, whereafter the conditional probability of failure increases rapidly (the wearout zone). Research has added the possibility of infant mortality, which then gives the well-known 'bath-ub' curve. A third age-related failure pattem is also encountered: where items exhibit a gradually increasing conditional probability of failure, but without any distinct wearout zone.

Failures which are not age-related are those where failure is totally random, and those where a high level of failure is encountered in the early stages of equipment use (the burnin or infant mortality stage), thereafter settling down to random failure.

Age-related failures are the basis upon which preventive (time-based) maintenance systems have been devised. Research in the civilian aviation industry (Nowlan \& Heap, 1978) has revealed that the percentage of failure modes which are age-related is $11 \%$. This means that the vast majority of failure modes encountered on civilian aircraft (89\%) are not susceptible to time-based maintenance, and traditional preventive maintenance is totally inappropriate. (No such analyses are known to have been done in the manufacturing industry, although the failure patterns discussed by Nowlan \& Heap certainly apply to industrial plant and equipment.)

Reassessment of current maintenance practice has taken place in two distinct and independent directions. One resulted from a greater understanding of how equipment fails, which was based on the research done by Nowlan \& Heap (1978) (leading to the industrial application of reliabilitycentred maintenance). The second has been an extension of the Japanese JIT approach: total quality and the total elimination of failures (total productive maintenance).

Each of these constitutes a new technology for any organization which adopts them. This is discussed by Moenaert et al. (1992) in their recognition of how firms (sometimes with ageing technologies) adopt new technologies from outside their sector, effectively 'dematuring' their activities. They refer to this as 'technological umaround', which demands taking on new technology as well as structural and managerial styles and processes. RCM is an example of a technology which was originally taken from a totally different sector. While TPM is a technology, not taken from another sector, it does, like other Japanese developments, require the adoption of a sea of practices which may be as foreign as adaptation from another sector. This may also necessitate the 'technological tumaround'.

There are two trends in maintenance which are highlighted by the implementation of RCM and TPM. These relate firstly to multi-skilling among craftsmen, and secondly to operators doing simple maintenance tasks. These present a paradox: one view is that management actions have changed work roles in order to encourage tochnological potential; the other perspective is that these developments are core to a neo-Fordist strategy aimed at achieving less extensive technological innovation by 'freezing the socio-organizational framework' (Jones, 1992: 302) in order to avoid the risks of excessive delegation. These are referred to again later.

A discussion of the two methods takes place at two levels: the underlying philosophies and their implementation. In the following paragraphs the philosophies underlying the two approaches are discussed. Elements common to each will be described, and areas of conflict will be highlighted. There is limited literature which analyzes these two approaches. In this article I therefore take the basic sources, and comment on them at a conceptual level. The main sources for describing reliability-centred maintenance are Nowlan \& Heap (1978), and Moubray (1991). The ariginal author of the books on total productive maintenance is Nakajima (1988, 1989). Further information on training in TPM is contained in the book published by the Nachi-Fujikoshi Corporation (1988).

\section{Rellabllity-centred maintenance (RCM)}

RCM was developed in the US civilian aviation industry and first documented in the literature (as MSG - Maintenance Steering Group) by Nowlan \& Heap (1978). Moubray defines RCM as:

'Reliability-centred maintenance is a process used to determine the maintenance requirements of any physical asset in its operating context' (1991: 7).

In order to determine the maintenance requirements, the RCM approach involves following a structured methodology which requires answers to seven questions (adapted from Moubray, 1991: 37):

1. What are the functions and performance standards of an asset in its operating context?

2. How does it fail to fulfil its functions?

3. What are the causes of each functional failure?

4. What happens when each failure occurs?

5. In what way does each failure matter?

6. How can each failure be prevented?

7. What should be done if no preventive task can be found?

RCM requires a precise definition of the functions of an asset (that is, by demanding details of the desired performance standards). It is thus a fundamental principle of RCM that maintenance can only yield performance up to a level commensurate with the inherent reliability of the equipment: that is, if the performance demanded of a machine is greater than its built-in capability, then maintenance cannot help to achieve the required perfomance level. This leads to the 
following definition of a failure (Moubray, 1991: 50): 'the inability of any physical asset to meet a desired standard of performance'.

RCM recognizes four categories of failure consequence: hidden failures (which have no direct impact, but are often protective devices which are not fail-safe), safety or environmental consequences, operational consequences, nonoperational consequences. RCM then follows a structured decision-making algorithm to determine what preventive maintenance (if any) should be adopted (condition-based maintenance, scheduled restoration or discard).

The nature of the failure characteristics of an item (agerelated or not) is relevant in deciding what maintenance task is appropriate. If a task is not technically feasible (a precise set of conditions needs to be adhered to for a task to be 'technically feasible') and worth doing (defined as providing the required level of performance for hidden and safety or environmental consequences, and cost effective for operational and non-operational consequences), then RCM suggests a series of default tasks. In the case of operational and non-operational consequences, the default is no scheduled maintenance, with possible redesign. With safety or environmental consequences, the default is compulsory redesign if a failure cannot be prevented. In the case of hidden failure consequences, the default is a failure-finding task (that is, checking whether an item has failed), or possible redesign.

The RCM approach developed by Nowlan \& Heap (1978) gives little indication of how a maintenance programme should be developed. The human dimension is thus not part of their underlying philosophy. Moubray (1991) strongly suggests that groups of suitably trained members should perform RCM analyzes. The groups comprise production and maintenance supervisors, logether with operators and craftsmen, and specialists as required.

\section{Total productive maintenance}

The five essential features of TPM are (Nakajima, 1989: 6):

1. Maximizing equipment effectiveness;

2. Development of productive maintenance for the life of the equipment;

3. Involvement of all disciplines (engineering, design, production and maintenance) in TPM;

4. Active involvement of all employees; and

5. Promotion of TPM through motivation management: autonomous small group activities.

Nakajima (1988: xix) states that the first is achieved by 'the complete elimination of failures, defects and other negative phenomena' (that is, of course, central to the Japanese zero defects philosophy). He points to the fusing logether of the traditional maintenance and production functions as acceptance that operators can be expected to do some maintenance tasks. The company-led small group activity, similar to the quality circle approach, is 'consistent with Likert's participative management model ...' (Nakajima, 1988: xx). Overall efficiency, which includes economic efficiency, is achieved by minimizing the costs of upkeep and maintaining optimal equipment conditions throughout the life of the equipment '... by minimizing life cycle cost' (Nakajima, 1989: 10).
TPM establishes a maintenance plan for the entire life of equipment, by including maintenance prevention (MP: by which is understood maintenance-free design), preventive maintenance (PM) and maintainability improvement (MI: repair or modification to prevent failures). All encompassing is the notion of autonomous maintenance by operators.

TPM seeks to eliminate what Nakajima (1988: 14) terms the 'six big losses': equipment failure, set-up and adjustment, idling and minor stoppages, reduced speed, process defects and reduced yield. TPM aims to reduce minor stoppages by lubrication, cleaning, performing adjustments and conducting inspections to be done by operators with maintenance staff performing 'periodic inspections and preventive repairs' (Nakajima, 1988: 33).

Only one failure pattem is acknowledged in the TPM philosophy, and this applies to all equipment: the bath-tub curve. TPM further identifies two types of losses (Nakajima, 1989: 39): chronic (occurring repeatedly) and sporadic (sudden outbreaks) losses. The remedy for sporadic losses is restoration because these are caused by changes in conditions. Sporadic losses are conspicuous. Solving chronic losses requires innovation. These are hidden (in TPM terminology, but not in the RCM interpretation of hidden failures) and may be exposed by measures such as cleaning and lubrication, adherence to proper operating procedures, restoration, rectifying deficiencies in design and improving operating and maintenance skills.

Once a failure has been identified (defined by Nakajima [1988: 39] as an occurrence that 'results in loss of a standard function'), two types of maintenance are recognized by TPM: preventive maintenance and autonomous maintenance. The former refers to tasks such as restoration, improving inadequate designs and eliminating inferio equipment. Autonomous maintenance involves basic cleaning and lubrication, autonomous inspection, organization and orderliness.

The scope of work is determined by teams (akin to quality circles), organized within the organizational structure by forming small overlapping, largely uni-disciplinary groups. These are constituted under the auspices of a TPM Master Plan.

\section{Comparlson of some of the underlying philo- sophies of RCM and TPM}

It is not possible to categorize each issue presented below as 'philosophical' or 'implementational' simply because some concepts are key to the philosophy of one approach, but these may not be of fundamental importance to the other. There are several similarities and essential differences between the two concepts. These are considered below:

- The basic premise underlying RCM is the idea that maintenance can help to achieve the inherent capacity of an asset, but cannot produce performance levels beyond its inherent reliability established by design and manufacture: hence the name reliability-centred maintenance. This requires precise definitions of the functions of equipment and their associated functional failures. TPM recognizes the intrinsic reliability of equipment, but does not relate this to operational reliability other than by 
saying that the product of the two (intrinsic and operational reliability) represents total reliability. Nakajima (1989: 53) alludes to the importance of design capability versus desired performance by saying that 'If restoration does not eliminate breakdowns, then efforts should be made to improve equipment, (but) this does not apply to equipment that cannot satisfy technical or market requirements'. In not making the conceptual differentiation between capacity and desired performance, the precise definitions of functions and failures are not an issue in TPM.

- The consequence evaluation in RCM is not addressed in TPM. While TPM speaks of hidden failures, these are not what is meant by hidden failures in RCM terminology or dormant failures (another word used for hidden failures - see for example, She \& Pecht, 1992). This is a weakness in TPM as over a third of all failures in modem plants can be hidden, and this will increase as the number of protective devices installed in automatic and hazardous environments escalates. TPM makes no specific provision for failure-finding tasks (also known as detective maintenance).

- Predictive maintenance is acknowledged by both RCM and TPM by their recognition of the importance of condition monitoring. RCM devotes much attention to the basis of determining the frequency of on-condition tasks. This is not addressed by TPM (which states Nakajima, 1989: 91, that equipment should receive attention at 'reasonable intervals'). This again represents a major weakness in TPM, as many practitioners in this field believe in the fallacy that criticality of equipment should determine the frequency of condition monitoring.

- Both approaches deal with scheduled restoration and scheduled discard (and in that order) to be followed by redesign, although TPM does not require redesign if maintenance cannot prevent a failure which can result in safety or environmental consequences. TPM does not specifically deal with failures which have safety or environmental consequences, presumably because of the belief in zero defects whereby unsafe situations cannot develop from equipment failure. TPM acknowledges that zero defects may be a long term goal, and that quantified incremental improvements are required. RCM rejects this in the case of safety and environmental consequences because killing less people this year than last year is an unacceptable management practice.

- RCM accepts that when the cost of prevention exceeds the cost of failure (including loss of production and associated secondary damage), it is not cost effective to eliminate all failures. TPM believes that costs are minimized when breakdowns and defects are eliminated. By following this zero defects philosophy, TPM is effectively treating maintenance as an infinite resource.

- The second and sixth TPM 'big losses' are set-up and adjustment times, and reduced yield from machine start-up to stable production. These two are common to Japanese manufacturing philosophy and deemed vital to successful manufacturing, by writers such as Milgrom \& Roberts (1990) and Bahrami \& Evans (1989); yet, none of these mention the maintenance aspect which in practice determines whether the shor set-up and adjustment times can be achieved. RCM mentions set-up as a problem to be addressed by failure mode analysis, but not as integral to the overall approach.

- TPM places great emphasis on cleaning and lubrication. While RCM accepts the necessity of these tasks, it does not adopt these as part of a zero defect, machinenurturing philosophy.

- TPM specifies a TPM Master Plan, with great attention being paid to top management commitment. Organization and training receive detailed attention, in order to ensure the success of TPM implementation (Nachi-Fujikoshi, 1988). As will be seen later, autonomous maintenance required by TPM, whereby operators do many basic maintenance tasks, is not accepted without resistance in Western countries (Hipkin, 1992). Nevertheless, the Japanese penchant for people issues is again illustrated by the comparison of western and eastem maintenance systems.

- Both RCM and TPM recognize that bum-in and random failures are in part maintenance problems. This view is expanded by Bowles (1992) who concludes, like the two maintenance approaches, that more than traditional tests and inspections in the manufacturing process are required. These problems should be addressed by preventive maintenance tasks and redesigns.

- Jayabalan \& Chaudhuri (1992) raise a key issue regarding restoration: with scheduled overhauls, the system does not regenerate watly, so as the failure rate of the system worsens, so the interval between successive maintenance interventions should be reduced as the system ages. This is not addressed by TPM. RCM requires that the restoration task must restore the original resistance to failure: in other words, regeneration of the system is essential for restoration to be technically feasible.

\section{Comparison of implementation methods}

The RCM implementation process is described by Moubray (1991), whereby groups are assembled to analyze items of plant. The RCM approach believes it is essential to have production and maintenance represented when maintenance policies are being set. RCM concentrates on the technology of maintenance (such as consequence evaluation and the technical feasibility and effectiveness of maintenance intervention). TPM differs totally in this respect: the groups are an integral part of the underlying philosophy, but the TPM philosophy does not address maintenance technology in much depth. This is an interesting finding as it typifies a more general difference between the western and eastem approaches to management: the western theories have concentrated on technology (analogous to the MRP emphasis on the technical issues surrounding the master production schedule), whereas the Japanese style has been one which pays great attention to people issues (with JIT emphazising the role of people in the attainment of zero inventory). By advocating production and maintenance working together, RCM addresses specifically some of the organizational problems which bedevil manufacturing: the antagonism between production and maintenance, and the suspicion between senior and junior levels. 
TPM has litule to offer on the technical front. This is reinforced by Kelly:

'... there is nothing new in the systems area. Indeed most of these concepts and systems have long been established in the USA and Europe, ... (but) it is in the area of human factors management that we have most to leam from the Japanese' (1992: 1Off).

The techniques proposed have been used extensively for some time. TPM demands total commitment by all levels of management, who are obliged to support the work of the groups. Group members are expected to be steeped in the JIT approach to manufacturing.

\section{Strateglc and organizational implications}

Maintenance is seen as a discipline which assists in enabling technology to be used in enhancing corporate strategy; this is technology strategy. Morone (1989: 96) sees the difficulty lying in bringing 'the potential opportunities that technology creates to bear on the formulation of corporate strategy': the strategic use of technology. It is easy to visualize RCM and TPM as tools for achieving technology strategy. It is not evident precisely how innovative companies can build corporate strategy around their maintenance. The choice would therefore appear that of choosing which maintenance approach will best help, at an operational level, to achieve strategic objectives.

It is at the operational level that Loveridge \& Pitt recognize that the origins of any technology are significant in strategy implementation:

'Strategists have become aware of the centrality of the culture of the organizations and of the sector from which it derives its operational norms' (1992: 2).

The Japanese approach to manufacturing in general no longer constitutes a totally new cultural concept to many organizations; likewise, a simplistic view of RCM would see the use of groups as a variation of quality circles. What is new is that maintenance, traditionally viewed as a supporting function, now provides the stimulus for profound effects on the organization. Studying the impact of a new maintenance philosophy requires exploring the linkages between innovation and corporate strategy' frequently neglected by strategists (Loveridge \& Pitt, 1992: 2). The application of technological innovation in this instance extends from a consideration of the engineering and organizational demands.

This is particularly true of RCM which, by relating performance requirements to inherent capacity, audits any design, and then imposes a rigid methodology on setting maintenance policies. One of the greatest challenges to the technology imposed by RCM is the analysis of protective systems: more automation means more hidden functions which in tum require specific maintenance intervention, based on multiple failure probabilities. Organizational systems need to be created to deal with the operational realities of additional layers of technology. RCM does not offer the choice of generating managerial options for innovation and change (Teece, 1985): it demands specific action.

In maturing industries, Morone (1989) believes that it is essential to 'dematurize' the dominant technology. By choosing to defend an old technology, firms effectively encourage competitors to enter the market with a new tech. nology, 'unhampered by entrenched competitors'. This applies as much to new technology in machines as it does in the maintenance thereof. In the maintenance field, the 'dematuring' would be dispensing with preventive maintenance systems based solely on time-based intervention.

The main challenge in implementing policies such as RCM and TPM lies in the organizational field. Jones (1992: 305) points to the fundamental paradox that in using new technologies, managers must cede control to lower levels. Because managers are reluctant to do this, they fail to secure the strategic advantages because of the insistence on retaining the conventional Fordist paradigm. This results in an uncertainty as to whether more decentralized and diffuse decision making '... is compatible with secure strategic control from the top' (Jones, 1992: 293). Applying this to the maintenance situation, new technology is broadly expected to create less specialized and more responsible jobs. The question which has not been answered is whether the less specialized individual will be able to deal with the increasing complexity of modern equipment: already this is questioning the long-term feasibility of multi-skilling. (Even the days of the most common multi-skilled craftsman, the motor mechanic, are numbered: motor mechanics are resorting more and more to wholesale replacement of parts and out-work.)

This is reinforced by Jones who suggests that combinations of technology and methods (which is broadly what RCM and TPM represent) are

"either consistent with Fordist philosophy, or are clustering into separate and distinct types, ... rather than all converging into a single system' (1992: 298).

Jones goes on to question the extent of multi-skilling:

'Apart from a consistent but only sporadically successful campaign to integrate electrical and mechanical maintenance roles, most change seems to have involved adding on minor product inspection and checking tasks to the same routine production jobs'.

The redundancy of some existing supervisory roles is most evident in the rapid demise of the maintenance foreman.

The neo-Fordist management approach is supported by several actions relating to the maintenance function, whether it is RCM or TPM: in order to retain control and span of discretion, rigid occupational specialization is appealing to management; conventional supervision and job descriptions remain. Unions see the fusing together of positions on the factory floor as a process which will reduce their power. Inter-union rivalry becomes intense if separate production and technical unions exist: frequently, operators are replaced by fitters and electricians who now operate and maintain a machine. The skilled craftsman has the ability to leam to operate a machine as well as to maintain it, whereas the operator may not have the technical propensity for maintenance. The operator is therefore the one dispensed with. At this stage there is no certainty that management is prepared to empower the lower levels as suggested by RCM and TPM: managers still fear the abdication of the managerial prerogative. 


\section{Conclusion}

In this article I have described briefly the reliability-centred maintenance and total productive maintenance processes. I have pointed out similarities and differences. The main conclusion is that RCM has a far more prescriptive methodology which relates design capability with desired performance. RCM evaluates failure consequences before suggesting what preventive maintenance is technically feasible and worth doing. It deals specifically with hidden functions and associated failure finding tasks. RCM recommends the use of groups to analyze equipment. TPM proposes five essential features which aim for zero defects through the involvement of all disciplines and the use of groups for autonomous maintenance. It seeks to eliminate the 'six big losses', with great emphasis on the human aspect of maintenance.

There is no definitive conclusion as to whether managers are prepared to accept totally the concept of innovative group decision-making and work arrangements by lower levels in the organization. Retaining hierarchical control may still be more appealing to managers. Should this be the case, the group approaches suggested by both RCM and TPM will not yield the tangible and intangible benefits which each system would claim. It is still possible to benefit technically from the RCM methodology. Without acceptance of the management approach demanded by TPM, this philosophy has litule to offer. The advances in sophistication and automation in manufacturing have to be met by effective maintenance. This means a safe and environmentally acceptable manufacturing facility which meets its design and protection expectations. RCM and TPM may be viewed as yet another pair of three letter abbreviations, but they do offer strategic direction to a vital management discipline that has suffered through neglect by both researchers and practitioners.

\section{References}

Bahrami, H. \& Evans, S. 1989. 'Strategy making in high-technology firms', California Management Review, Vol. 31, Summer 1989: 1-22.

Bowles, J.B. 1992. 'A survey of reliability-prediction procedures for microelectronic devices', IEEE Transactions on Reliability, Vol. 41, No 1, March 1992: 3-12.

Gold, B. 1989. 'Computerization in domestic and international manufacturing', California Management Review, Vol. 31, Summer 1989: 127-143.
Hayes, R.H. Wheelwright, S.C. 1984. Restoring our competitive edge. Chichester. John Wiley \& Sons. 427pp.

Hipkin, I.B. 1992. A study of changes in skills profiles in manufacturing industries. Unpublished discussion paper. Cape Town: Department of Business Science, University of Cape Town.

Jayabalan, V. \& Chaudhuri, D. 1992. "Cost optimization of maintenance scheduling for a system with assured reliability'. IEEE Transactions on Reliability. Vol. 41, No 1, March 1992: 21-25.

Jones, B. 1992. 'New production technology and work roles', in Loveridge, R. \& Pith, M. (eds.). The stralegic management of technological innovation. Chichester: John Wiley \& Sons. 404pp.

Kelly, A. 1992. 'The uses and limitations of total productive maintenance', Maintenance, Vol. 7, No. 3, September 1992: 3-13.

Loveridge, R. \& Pith, M. (eds.). 1992. The strategic management of techrological innovation. Chichester: John Wiley \& Sons. 404pp.

Milgrom, P. \& Roberts, J. 1990. 'The economics of modern manufacturing: technology, strategy and organization', The American Economic Review, June 1990, pp 511-528.

Moenaert, R., Barbé, J., Deschoolmeester, D. \& De Meyer, A. 1992. 'Turnaround strategies for strategic business units with ageing technology', in Loveridge, R. \& Pith, M. (eds). The strategic management of technological innovation. Chichester: John Wiley \& Sons. 404pp.

Morone, J. 1989. 'Strategic use of technology', California Management Review, Vol. 31, Summer 1989: 91-110.

Moubray. J. 1991. Reliability-centred maintenance. Oxford: Butterworth-Heinemann Ltd. 320pp.

Nachi-Fujikoshi Corporation. 1988. Training for Total Productive Maintenance. Cambridge, Massachusetts: Productivity Press. 259pp.

Nakajima, S. 1988. Introduction to Total Productive Maintenance. Cambridge, Massachusetts: Productivity Press. 129pp.

Nakajima, S. 1989. Total Productive Maintenance: development programme. Cambridge, Massachusetts: Productivity Press. 403pp.

Nowlan, F.S. \& Heap, H. 1978. Reliability-centred maintenance. Springfield, Virginia: National Technical Information Service, US Department of Commerce. 466pp.

She, J. \& Pecht, M.G. 1992. 'Reliability of a k-out-of- $n$ warmstandby system', IEEE Transactions on Reliability, Vol. 41, No. 1, March 1992: 72-75.

Teece, DJ. 1985. 'Applying concepts of oconomic analysis to strategic management', in Pennings, J.M. (ed.). Organization stralegy and change. San Francisco: Jossey-Bass, pp 35-63. 